\title{
Primary cutaneous marginal zone B-cell lymphoma
}

INSERM

\section{Source}

INSERM. (1999). Orphanet: an online rare disease and orphan drug data base. Primary cutaneous marginal zone B-cell lymphoma. ORPHA:178536

A rare, indolent primary cutaneous B-cell lymphoma characterized by multifocal, red to violaceous papules, plaques or nodules localized predominantly on the trunk and extremities. Histologically, these are dermis infiltrates consisting of small, marginal zone B cells, lymphoplasmacytic cells, and plasma cells. Marginal zone B cells express CD20, CD79a and BCl-2, and are neg ative for CD5, CD10 and Bcl-6. Plasma cells are typically located at the periphery, and express CD138, CD79a, and monotypic light chains. 